\title{
Enchanted by Barely-an-Animal in Not-Quite-a-Wilderness ${ }^{1}$
}

\author{
Jeffrey A. Lockwood ${ }^{2}$
}

\begin{abstract}
Several conventional criteria qualify particular animals to be subjects of nature writing and specific places to be objects of literary awe (e.g., being beautiful, virtuous or frightening). Whales, wolves and gorillas are the 'standards' for many environmental essays, and the Grand Canyon, the High Sierras, and the Amazon basin are locations that provide the sort of spectacle we've come to expect from nature. In this essay I explore the possibility that rather more prosaic creatures and less sublime places might provide valuable insights about the natural world and ourselves. I suggest that freshwater mussels-however lacking they may be in the qualities that we traditionally value in animals - are the iconic creatures of Isle Royale, a place that reflects the unexceptional nature of our lives. And from these connections, I hope that the reader comes to see that it is possible to truly appreciate the ordinary beings, settings, and events that infuse our daily existence.
\end{abstract}

Key Words: freshwater mussels, Isle Royale National Park, aesthetic value, utility value, literary conventions, spectacle, ordinariness

In even-numbered years, I'm glad that I have a television. The Olympics are appallingly professionalized and commercialized, but I love watching anyway. My fellow humans push themselves to achieve remarkable feats of strength, speed, agility and endurance. And beginning in 1912, the Olympics included architecture, literature, music, painting, and sculpture (along with medals in these 'events'). Although these competitions were dropped in 1948, in keeping with the spirit of the London Games I decided to seek a genuine literary challenge. ${ }^{3}$

\footnotetext{
${ }^{1}$ Submitted on January 3, 2013. Accepted on January 21, 2013. Regarding the footnotes in this essay, I added these after the review process to address various scientific, philosophical, and sociopolitical concerns raised by well-meaning academics (e.g., "A mussel is fully an animal; there are no such things as degrees of being an animal"). Just how a nature essay 'works' in the context of a scientific journal is something of an experiment, and the footnotes are an attempt to bridge these realms (e.g., in writing, it is evocative to suggest that a shelled creature without familiar body parts is "barely-an-animal"). It might help if the scientist thinks of an essay as a kind of model, insofar as models involve simplifying assumptions, reasonable approximations, and selection of relevant variables in the pursuit of understanding some aspect of the world. Or as George E.P Box put it: All models (essays) are false (imprecise), but some are useful (enlightening).

${ }^{2}$ Professor of Natural Sciences \& Humanities; Master of Fine Arts in Creative Writing program and Department of Philosophy, University of Wyoming, Laramie, WY 82071; lockwood@uwyo.edu

${ }^{3}$ Here is the first scientist-essayist collision. A reviewer was of the opinion that beginning the essay with an allusion to sports was boring because that individual didn't follow the Olympics and hadn't a clue who Michael Phelps was (he comes later-and Phelps won more Olympic medals in his swimming career than any other athlete, in case you're also perplexed). Don't be surprised when the glory of Olympic athletes versus the ingloriousness of most people's lives comes back as a way of perceiving the nature world. But feel free to ignore all of the footnotes, unless you're uncomfortable with a bit of literary irony and imaginative playfulness or you're interested in how to negotiate the 'ecotone' between creative and scientific non-fiction.
}

DOI: 10.9784/LEB1(1)Lockwood.08 
As fortune would have it, I was selected to be an artist-in-residence at Isle Royale National Park and began my 2-week stint just as the 2012 Olympics were ending (Figure 1). Isle Royale is mostly wilderness, a place where people go to face challenges (although not typically while hanging out in a charming artist's cabin perched on a cliff overlooking Lake Superior). I've frequently written about insects, grasshoppers in particular, which would seem to be challenging enough. But I wanted a subject that would truly stretch my limits.

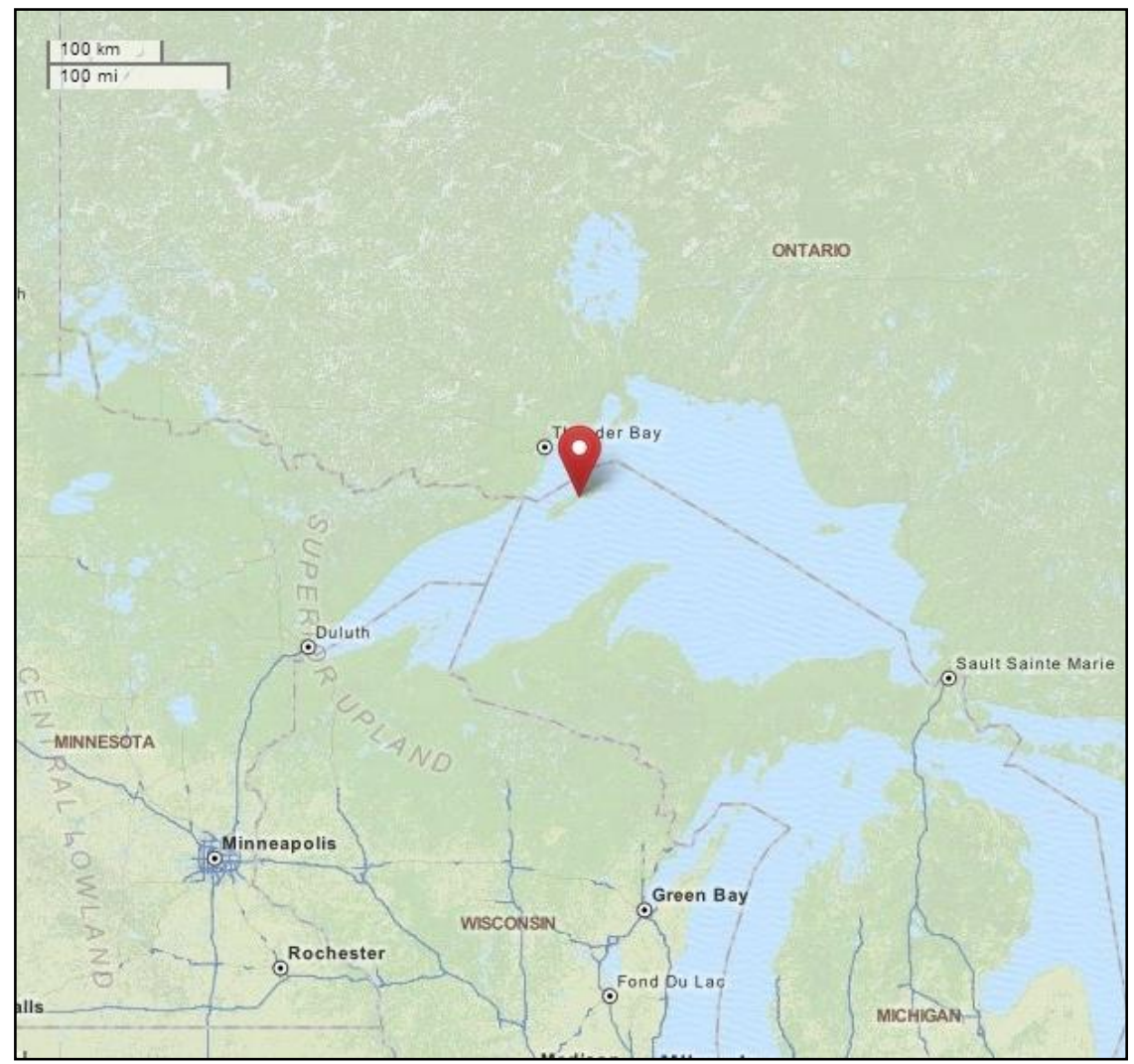

Figure 1. Isle Royale National Park consists of one large island $(72 \times 14 \mathrm{~km})$ along with 450 smaller islands in northwest Lake Superior, at $48^{\circ}$ latitude (approximately that of Munich, Volgograd, and Ulan Bator) and $-89^{\circ}$ longitude (approximately that of New Orleans, San Salvador, and the Galapagos Islands).

Charismatic megafauna are at the heart of outdoors literature and these creatures present a certain challenge. An editor once told me that it was possible that something more needed to be written about whales or wolves, but he was rather dubious. Surrounded by Lake Superior, Isle Royale has no whales; 
however, it boasts both wolves (currently just nine spread over 535 square kilometers, but I overheard several visitors say that they'd heard one howling) and moose (supposedly quite numerous, but given that I encountered only tracks and droppings in nearly 160 kilometers of hiking, "moose" appears to be a pasttense noun).

My research began at the Park's visitor center, where I found postcards limited to furred and feathered animals. In our cabin, I discovered The Island Within Us, an anthology of works by Isle Royale's artists in residence. The text and images included plenty of allusions to animals with nearly half involving birds (loons being the winner), while moose-and-wolves took care of another quarter, with the rest allocated to all other creatures (such as squirrels, fish, and mayflies). Not surprisingly, artists are pretty much like naturalists when it comes to noticing other species. ${ }^{4}$

In thumbing through the nature and hiking guides in our cabin, I tallied the number of photos devoted to various creatures. One-third were of birds, a quarter were devoted to wolves and moose, $15 \%$ each were allocated to other mammals and fish, and 5\% each depicted amphibians/reptiles and insects (mostly butterflies although the most conspicuous and prevalent insects on my hikes were surely grasshoppers). Among the hundreds of photographs there was one picture of the most naturalist-forsaken invertebrate, a truly uncharismatic bit of fauna: The freshwater mussel. Now here was a worthy subject.

Crafting a readable essay about mollusks would be tantamount to an Olympian running a sub-2 hour marathon. ${ }^{5}$ Moreover, I'd assured the Park that my writing would capture essential qualities of Isle Royale. Seeing a 72kilometer long boreal-forested, lichen-encrusted, bog-pocketed crest of basalt through the eyes of a mussel (which actually lacks eyes) would be an Olympian - even Herculean - task. Clearly, I needed a strategy to portray America's least visited Park in terms of its least appreciated organism. What makes another life form writable? Based on my having read countless essays, poems, and stories about animals and places, I settled on six non-exclusive qualities of conventional nature writing. ${ }^{6}$ A creature worthy of the pen can be

\footnotetext{
${ }^{4}$ They also have a great deal in common with nature writers. Now some professor of environmental literature is sure to take me to task for this, but I agree with David Quammen who wrote: "There have been too many purple effusions by one writer or another standing out in a forest or a meadow, misted by rain or spring pollen or pheromones and transfixed by the spectacle of his or her own sensitivity." As soon as I come across the first majestic grizzly in an essay or soaring eagle in a poem, I run the other way.

5 Aesthetic and utilitarian values are important motivations for National Park visitors. They like seeing bears and hearing how wolves provide 'ecosystem services'. These people are the primary audience for this essay. Academic scientists and philosophers should imagine themselves on vacation at a National Park — relax and stop thinking so much. If they are seeking a primer on mussel biology or an erudite critique of environmental ethics, I suggest reading technical papers in these specialized fields like I did.

${ }^{6}$ I have no doubt that a professor of environmental literature will object to my characterization of the genre. If so, then pick the qualities that you think are represented in writings about animals, and
} 
intriguing, beautiful, profitable, humanlike, virtuous, or scary. Surely freshwater mussels would qualify in at least one of these regards and thereby serve as a portal to Isle Royale. Or so I hoped.

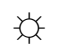

To begin, a viable subject for a nature essay can provide intellectual intrigue. Some creatures lead complicated lives, such as whales and wolves with their elaborate forms of communication, social hierarchies, and problem-solving skills. Mussels, however, are not complicated. They are just confusing. At least their taxonomy is a mess. People are understandably perplexed by what distinguishes a mussel from a clam. Both are bivalves (having two shells bound together by a ligament), so what's the difference? "Mussel" usually refers to marine bivalves that attach themselves to solid surfaces and pair well with garlic butter and a crisp Chardonnay. However, there are inedible, freshwater mussels. Even the Park Service jumbles the terms: "Also known as mussels, clam populations at Isle Royale...". As near as I can figure, clams are typically round and symmetrical, while mussels have elongated shells that are internally iridescent. So, the island's bivalves are definitely mussels (Figure 2).

Some creatures intrigue us by virtue of being environmentally fragile. Peregrine falcons with DDT-thinned shells make for great nature writing. As for fragility, the mussels of Isle Royale belong to the family Unionidae which is very sensitive to pollution. Thanks to Homo sapiens, of the 300 North American species known from the 1800s, 37 are extinct and more than a hundred are imperiled. Some species have extremely restricted ranges, so even small-scale impacts can be devastating. However, those on Isle Royale are not endangered or endemic. They're just regular old mussels. The greatest risk is if the invasion of a malevolent mollusk, the zebra mussel (which is actually a clam), extends to the island. But as every crime writer knows, perpetrators are always more interesting than victims.

I'll bet that mussels fare about the same with these conventions. The qualities are likely to reflect instrumental values that entail a consumptive or non-consumptive good for humans. Some philosophers and environmentalists ascribe to nature having intrinsic value (a mussel is good in and of itself). I've taught this in my courses on environmental ethics but I don't believe it. I want to believe it, but nobody has provided a plausible account of intrinsic value in my estimation. If mussels have it, and bacteria have it, and rocks have it, and asteroids have it, then what doesn't have it? And if everything has it, then it doesn't mean a whole lot in terms of valuing nature, unless some things have more of it — but then how would we know? 


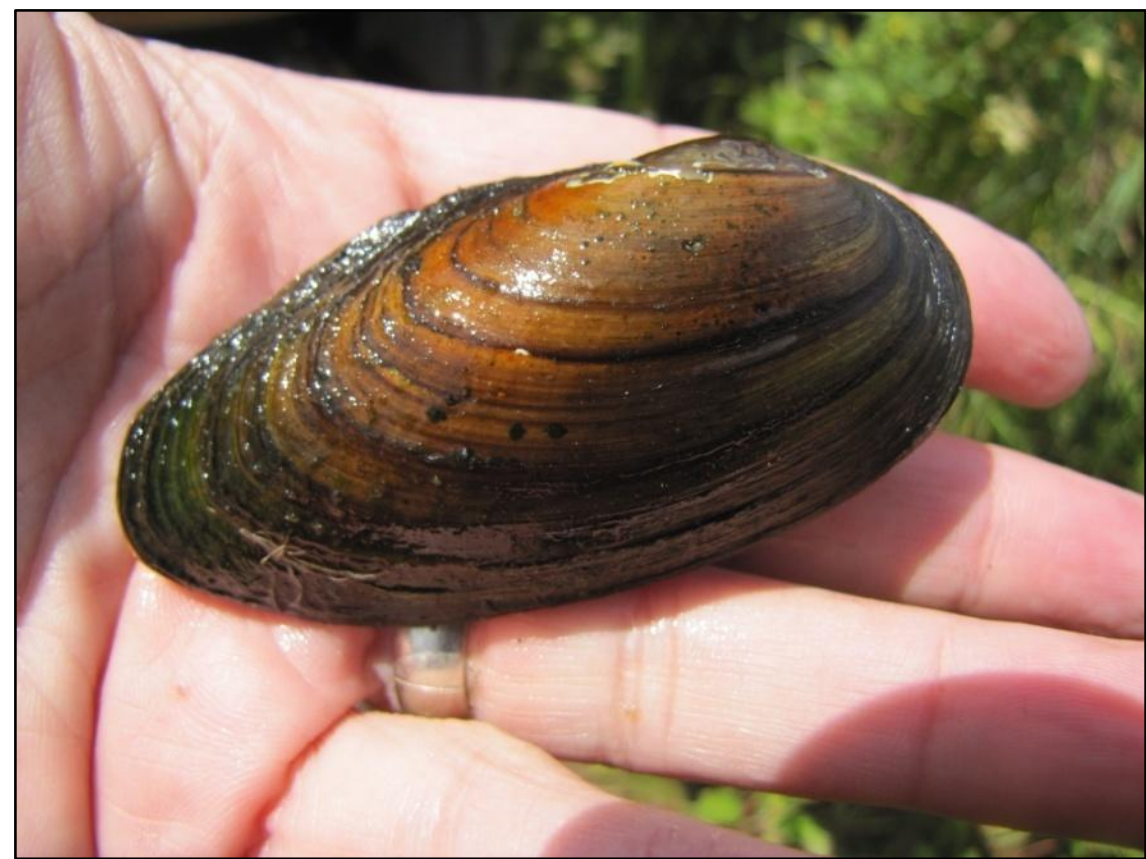

Figure 2. A freshwater mussel lacking in great beauty, but prettier than some rocks and more interesting than liverworts and mosses (although this may be debatable).

Biological diversity can also be a source of wonder, as evidenced by the rows and rows of books written about birding. But alas, there are just four species of mussels on Isle Royale. Some of the inland lakes have absurdly high abundances of these animals. But they're just the same thing over and over, like the playlist of an oldies AM station. Ronald Regan should've picked on Isle Royale's mussels - rather than California's trees - when he decreed: "If you've seen one redwood you've seen them all."

Finally in terms of intellectual intrigue, some animals are mysterious. We are enchanted by the homing ability of pigeons, the migrations of wildebeests, and the dance language of honeybees. However, the mussels of Isle Royale are rather prosaic. ${ }^{7}$ The biggest mystery is why there are so many of the things in

\footnotetext{
${ }^{7} \mathrm{Be}$ assured that I'm keenly aware of the literature on environmental aesthetics (having even published in this field). Although aesthetic relativism is a vacuous position (beauty being purely "in the eye of the beholder" is a philosophical non-starter), some aestheticians argue that all natural objects and processes can be "interesting", which is taken to be an aesthetic quality, particularly by those in the cognitivist camp. I'm dubious (as are many others) that the form, function, and origin of everything in nature is aesthetically compelling. Or at least equally so. As such, I'm sticking with my judgment that mussels are prosaic — but, as we shall see, this quality doesn't entail that they are devoid of great potential as evocative metaphors. So keep reading and quit nitpicking...
} 
some lakes (Chickenbone Lake has 6.4 million mussels or nearly 100 per square yard, although I can attest to this density being an overestimate at the east end of the lake, at least at depths up to my shorts), while other lakes have none (Figure 3 ). And they don't occupy the rivers at all, which is not the case on the mainland. It's probably just a matter of patchy geology. They love sand and gravel to burrow into, along with calcium for their shells, while they hate copper which is pocketed on the island, as Native Americans and European miners discovered. So the irregularity of mussels in the Park is not really the stuff of an environmental whodunit.

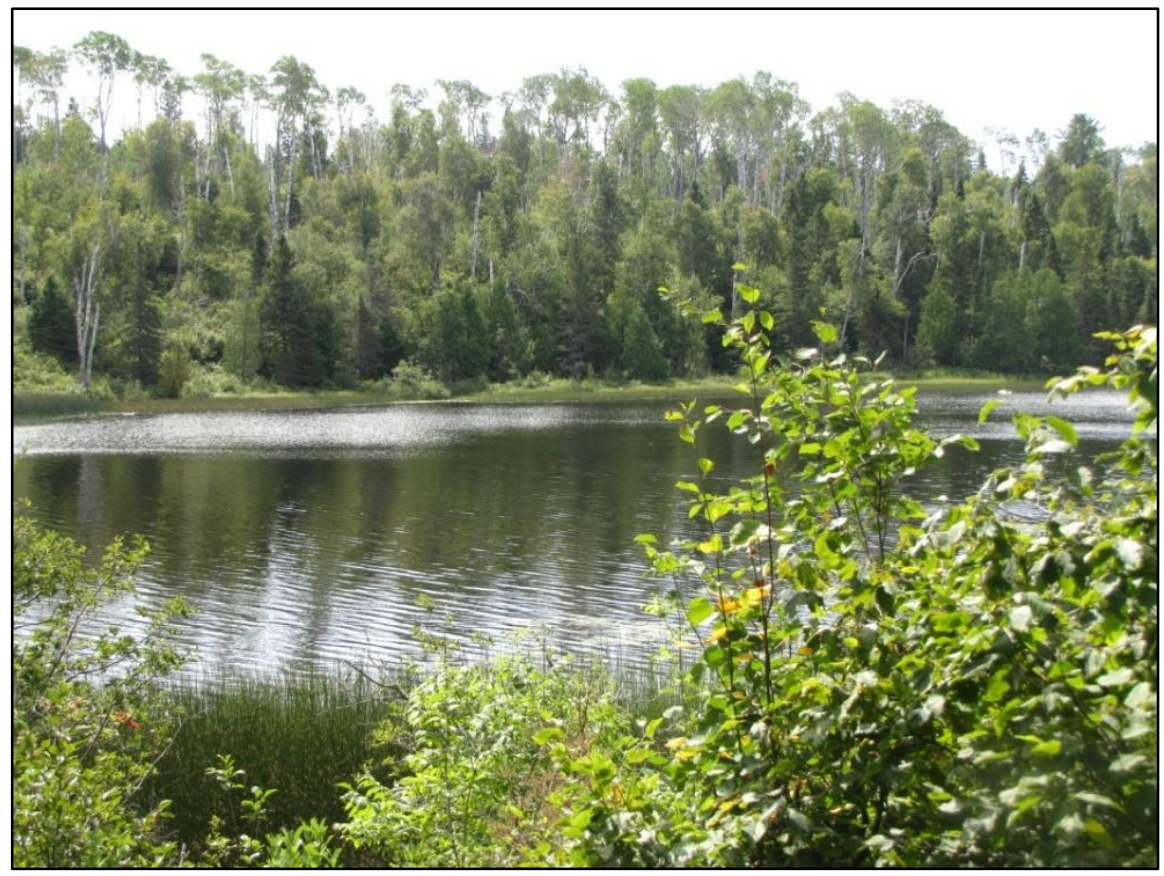

Figure 3. Chickenbone Lake, Isle Royale's haven for 6,500,000 freshwater mussels (along with a few moose and a whole mess of leeches).

If a creature fails to intrigue us, its appearance may still provide enough impetus for the nature writer. Some animals are pretty (Isle Royale has indigo buntings and luna moths) and others are beautiful (a great blue heron in flight over the island is simply sublime). Prose and poetry sing praises to the aesthetic glory of loons and lions.

Mussels are in the class Bivalvia within the phylum Mollusca, a name derived from mollis meaning soft. Although having mushy innards is 
aesthetically off-putting, the inside of a mussel's shell features mother-of-pearl (Figure 4). It's a bit gaudy, but more appealing than the slimy gray-pink organs that some people slurp from their relatives, the oysters. For decades, mussels were dredged from the rivers of the midwestern and southern United States (not the lakes of Isle Royale, however) to supply the button industry. Ever since plastic replaced shell, people have not had much reason to peer inside freshwater mussels. And if you have to work that hard for a colorful glimpse (opening mussels is as hard as writing about them), then beauty is not one of a creature's strong points. After all, the lustrous sheen of a warthog's peritoneum does not make a convincing case for the aesthetic quality of the animal itself.

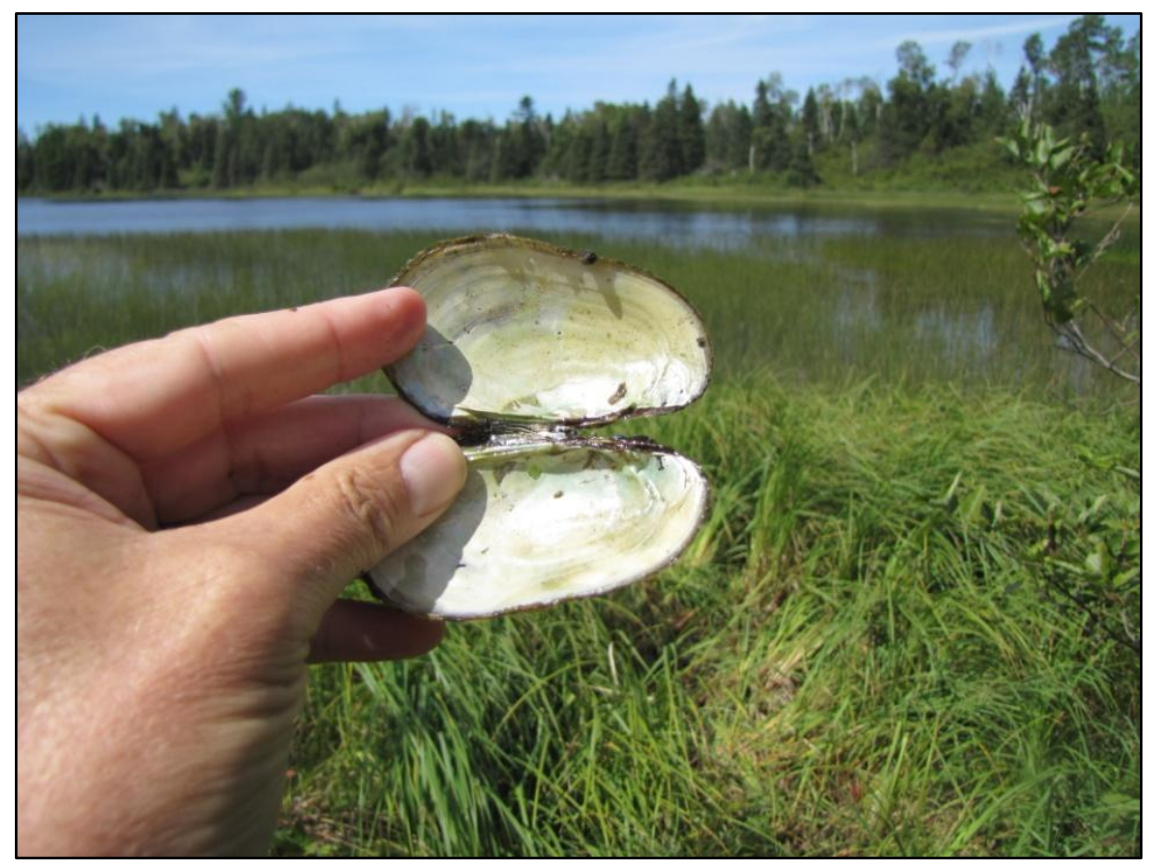

Figure 4. The inside of a freshwater mussel shell showing the nacre or mother-of-pearl interior which would make lovely buttons (an otter likely snacked on the bivalve and left the shell behind).

Mussels are also used in the creation of beautiful things, such as freshwater pearls. Unfortunately, the bivalve beasts on Isle Royale are the wrong kind for this sort of work. However, in principle they might be of value to the marine pearl industry. Fragments of freshwater mussel shells are ideal for seeding oysters, but that's not much of a ringing endorsement. It's a bit like claiming that sperm and pine cones are beautiful because babies and sequoias are marvelous. 
For organisms short on intrigue and beauty, nature writers have tapped into economic value. Crops and livestock aren't terribly interesting or beautiful, but foodies eat up any new book about edible life forms. Who'd really care about cod if the fish weren't money makers? Mussels are an enormously valuable food source, at least if they come from the sea. Some marine species, such as the blue mussel and the green-lipped mussel (not a brilliant marketing move in terms of naming), are tasty and profitable. People steam open almost 2 million metric tons of these bivalves every year. But alas, freshwater mussels are not on the menu unless you're a goose, muskrat, otter, or raccoon. Or perhaps a Native American, as they ate mussels - perhaps even indulging in those found at Isle Royale - but the modern palate finds these creatures to be inedible.

The Winnebago tribe ${ }^{8}$ had a thriving tool and utensil industry based on the shells of freshwater mussels. These people crafted tilling blades, knives, saws, spoons, cups, ladles, scoops, and fish lures. They even devised a special, shell tool for scalping their enemy. But the Winnebagos probably never made it to Isle Royale, and their economy has shifted from mussel shells to casino chips.

Today, the claim to utilitarian fame for freshwater mussels is their role in environmental monitoring. Their sensitivity to pollution means they are good bioindicators. So their value lies in their dying, which doesn't make for great literature. ${ }^{9}$ Mussels also accumulate heavy metals in the course of filter feeding, so they are handy chemical record-keepers. But again, building an essay on an organism's capacity to suck up and absorb copper, lead and cadmium is like telling a gripping tale of a furnace filter. Speaking of filters, mussels contribute to cleaning up municipal water supplies, although it doesn't look like the engineers at water treatment plants need to worry about their jobs. I would note, however, that the mussel population of Chickenbone Lake filters a volume of water equal to 80 Olympic-sized swimming pools every day. Let's see Michael Phelps do that.

Failing a profit motive, the desperate nature writer can play the anthropomorphism card. Jane Goodall's chimps were a primate soap opera and people watch television programs about personable meerkats. I admit to tearing up while reading Rick Bass's Brown Dog of the Yak and who didn't cry at the end of Old Yeller? However, connecting to non-human animals requires that we have something in common.

\footnotetext{
${ }^{8}$ These people call themselves the Ho-Chunk which should be respected — as noted by a reviewerbut $99 \%$ of readers wouldn't have a clue about this name. So I stuck with the much more commonly used name without intending offense.

${ }^{9}$ Some punctilious literature professor is sure to point out that there's great literature about death and dying (Hamlet, Death of a Salesman, and that heartrending final scene in Of Mice and Men). But making the loss of a mussel population from a polluted stream into literary tragedy is something of a stretch. Writers and ecotoxicologists probably suspect that Stalin was mostly right when he said, "A single death is a tragedy while a million deaths is a statistic." And Stalin wasn't even talking about bivalves.
} 
Mussels are pretty much the inverse of humans. ${ }^{10}$ Their sensory system is meager, with a crude capacity for touch or taste and "vision" is limited to detecting the shadow of a hungry predator. But they can't think, "Here comes a muskrat" because mussels don't have brains. In the course of evolution bivalves abandoned their heads, hence their $19^{\text {th }}$ century scientific name: Acephalia, meaning "without a head". While their molluscan relatives, the octopi and squids, are the geniuses of the invertebrate world, mussels are the dumb jocks. ${ }^{11}$ Their common name alludes to the muscles which clamp shut their shells, not their open minds. Although a mussel has cerebral ganglia (clumps of nerve cells), the main control center is the pedal ganglia, suggesting that its so-called foot is the focal point of neurological concern.

The foot is a muscular extrusion that looks more like a repulsively overgrown tongue. A mussel extends and contracts this structure to pull itself along in what passes for movement (you can watch a mussel for a very long time without detecting motion). In reality these creatures are couch potatoes compared to other bivalves that can climb, dig, and swim with remarkable, if not Olympian, facility. ${ }^{12}$

The clam in Disney's The Little Mermaid was oriented so its two shells formed a mouth. Mussels don't even get this right. They are oriented sideways, such that hinge of the shell is the "back" of the creature. If you tried to talk to a mussel, its speech would be muffled by having its face pressed into the gravel (scientists can figure out the ends of even headless animals).

In the poem, "The Tables Turned," William Wordsworth famously penned, "Let Nature be your teacher," and writers have often used animals to exemplify human virtues. Dianne Fossey's gorillas were noble and gentle; horses evoke the qualities of courage and grace as expressed in Black Beauty, National Velvet, My Friend Flicka, Seabiscuit, and the newest, sentimental favorite, War Horse. There're good reasons that mussels are missing from tales of animal virtue.

Nor is the sex life of a mussel on Isle Royale the stuff of steamy nature writing. As opposed to humans, there is no intimacy in mating. The males release sperm either continuously (termed "dribble spawning", suggesting the need for a mollusk urologist) or in batches triggered by environmental cues. A female sucks the sperm into her body in the course of filtering water and the

\footnotetext{
${ }^{10}$ It pains me to add this footnote, but based on the reviews it seems that some very scientifically inclined readers may be reading this essay quite literally and thinking that $\mathrm{I}$ am utterly contemptuous of mussels. There've been some rather ironic passages to this point and more are coming. Irony, for those who struggle with humor and imagination, is the use of words to convey the opposite of their literal meaning. Keep this in mind when it appears that I am disdainful of mussels or dismissive of Isle Royale.

${ }^{11}$ Note to the overly sensitive and politically correct reader who's likely to be an academician: I know that some athletes are smart. My son is a really bright distance runner. Lighten up and enjoy the essay.

${ }^{12}$ See footnote 10 .
} 
eggs are fertilized inside her gills, which is like combining a lung with a uterus. Weird sex can be titillating, but this is just bizarre.

The fertilized eggs develop into glochidia that are released into the water and latch onto fish. They embed themselves into the host's fins or gills for 2-5 weeks, after which they drop off and set up a shell house. This process allows mussels to disperse upstream (creeping long distances not being a viable option). Most glochidia die before finding a fish, except in a few species of Unionidae that have modified various body parts to imitate small fish and lure unsuspecting big fish into close proximity, at which point the glochidia are released. So freshwater mussels are parasitic frauds - not great material for stories of animal virtue. $^{13}$

As for the Isle Royale mussels, they don't live in the flowing water. Having settled into the lakes and a few bays, it seems plausible that they've lost the whole fish hitchhiking maneuver given that there isn't any need to recolonize upstream habitats ${ }^{14}$. If so, they're somewhat less reprehensible but also that much less interesting.

Writers also find inspiration in old and presumably wise organisms, such as silverback gorillas and matronly elephants. Here, the freshwater mussels might finally gain a foothold. While most scientists figure that these bivalves live for 10 to 100 years, some recent research suggests that life spans of greater than two centuries may be common. Unfortunately, for most of the mussel species on Isle Royale the oldest individuals are teenagers - not an age notable for its sagacity, at least in humans. The eldest individual on the island was estimated to be 62 years old, but can a headless animal be wise?

Happiness is perhaps the ultimate outcome of a virtuous life. And a mussel could be as "happy as a clam (at high tide)", being pleased not to be plucked and steamed alive. However nobody talks about the joy of freshwater mussels because their unappealing flavor is better protection than deep water. Although they appear contented, this is probably because they can't do much about their situation.

If all else fails, some creatures make good literary fodder by being scary. Essays featuring killer bees, man-eating tigers, deadly snakes, voracious piranha, and even virulent pathogens have made their way into nature writing. We love being frightened. Why else would people pack movie theaters to have

\footnotetext{
${ }^{13}$ As a reviewer took pains to point out, some glochidia may be commensalistic (not harming the fish) and some species don't deceive the host. Fine, but you can see where "commensalistic opportunists" isn't a very compelling description - and it's no more descriptive of the world of mussels.

${ }^{14}$ Note to biology students seeking a thesis project: This would be a keen line of investigation. Sure, it's speculative, but what's the fun of conducting a study if you already know the answer? Too much research is about incrementally and unimaginatively adding tiny bricks to the edifice of science. But I digress.
} 
the bejeezus scared out of them by the likes of Dracula, Freddy Krueger and a great white shark?

Mussels, however, are not likely to boost adrenaline. Some marine species accumulate nasty toxins and microbes. Paralytic shellfish poisoning is singularly unpleasant. And amnesic shellfish poisoning is alarming insofar as a toxin destroys brain cells causing memory loss, along with other troubling symptoms including death. But such awful diseases aren't associated with freshwater mussels.

The mussels of Isle Royale excrete pseudofeces (and actual feces) into the water, which is repulsive if not frightening. This organic gunk is expelled without passing through the digestive system, so it might be more properly called "mussel vomit". However, scientists failed to capitalize on this literary opportunity. ${ }^{15}$ And there's something alien, if not quite monstrous, about mussels using the same organ for multiple functions - the heart and kidneys participate in reproduction while the gills function in feeding. But these oddities are not much on which to hang an essay.

Finding freshwater mussels lacking in all of the classic qualities of writable creatures, my defeat seemed imminent. So I sat on the cabin's bench, sipped a glass of chilled wine (who would've thought that propane can be used to run a refrigerator?), and pondered the viability of my literary exercise. Contemplation is for writers what wind sprints are for athletes, and it struck me that in my failure I'd found the most important attribute of freshwater mussels. They are the perfect icons for Isle Royale. As self-appointed referee of the island's fauna, according to my arcane scoring system, wolves, moose, loons, thimble berries, black spruce, and old man's beard lichen cannot compete against the bivalves.

The mascot for the Park should reflect the scale of the island's setting, and Lake Superior holds $10 \%$ of the planet's fresh water. In the face of such enormity, nine wolves can't beat several million mussels. And given that almost $80 \%$ of the Park is underwater (thanks to a 7 kilometer buffer around the island), surely the iconic organism should be aquatic.

Isle Royale is the least visited National Park, with about as many people coming each year as arrive at Yellowstone on a busy day. The dearth of visitors reflects the difficulty of getting there via a long and pricey boat ride or a short and pricier floatplane ride. Likewise, mussels are hard to get to and rarely

\footnotetext{
${ }^{15}$ It was proposed, a bit condescendingly by a biologist, that pseudofeces should be called "mussel spit" (as if I had overreached). However, not only is some literary license allowable but the proposed term is both less vivid and less accurate. Pseudofeces is not merely a secretion.
} 
visited. Not only do they live underwater, but many of the park rangers aren't sure where to direct the would-be mussel viewer. ${ }^{16}$

Chickenbone Lake - the nirvana of mussels - is inconveniently located for those without time, equipment, ability or the inclination to backpack and camp. I took the 50 kilometer roundtrip (20 of the kilometers by hiking, the rest by underpowered aluminum boat) from our cabin and was rewarded with some rather nice, palm-sized bivalves. But I doubt many people would make the trek for the experience (besides, the lake is home to enormous, hungry leeches, which score well on the "scary" factor). I was going to take a shell back to the ranger station, given that their display of the island's animals somehow omitted the mussels. However, my wife admonished me that doing so was against Park policy, so I settled for photographs which a gifted taxidermist can surely convert into a breathtaking wall mount for our den.

The other reason for Isle Royale's low visitation rate is that the Park is closed most of the year. Given its northerly location, people stop coming in September and don't return until June. Likewise, mussels are closed most of the time. This seems like a good tactic for a long life, whether an island or a bivalve.

Mussels don't get much respect, and neither does Isle Royale-even from its own. The Park Service's annual newspaper for the island is downright apologetic:

National Parks are cherished symbols of our shared identity as Americans...Each place has significance. Yellowstone protects the largest concentration of thermal features on the planet...Zion has the world's largest freestanding arch and Yosemite, the continent's tallest waterfall. And then there's Isle Royale.

Ouch. The article goes on to list skunk cabbage among the Park's wonders. One has to wonder if the name "Isle Royale" is a kind of geographic compensation for a small island being surrounded by a Great-indeed, Superior-Lake. ${ }^{17}$

Add to this the fact that this island wilderness hosted copper mines, commercial fisheries, farming ventures, a lumber operation, and tourist hotels complete with a 9-hole golf course. The waters are littered with shipwrecks and the remnants of docks. Isle Royale is a wannabe wilderness, but then few people would list mussels as wildlife. They are wildlife but only by human fiat, much as the island is wilderness by political decree. You can't tell a domesticated bivalve

\footnotetext{
${ }^{16}$ To the reviewer who thought that this statement disparaged rangers, so it "needs checking and might be an overstatement," I asked four rangers where to find populations of mussels and only one had a clue. In their defense, I'd guess that somewhere around 1,000 visitors ask where to find moose for every one that asks about mussels (that claim might be an overstatement, but I doubt it).

${ }^{17}$ For the historians - it appears that the island was named in honor of Louis XIV, so even the French didn't perceive the place as being impressive in its own right.
} 
from a wild one, but given enough time maybe we won't be able to tell a recovered wilderness from a pristine one. ${ }^{18}$

Isle Royale is also geographically misclassified. It would belong to Canada, except for a cartographic error when the US-Canadian border was drawn in $1783 .{ }^{19}$ And it's a bit hard to rationalize how mussels are classified as animals. Sure, they have innards that are vaguely reminiscent of those in reptiles, birds and mammals, but even insects have their organs more properly organized than bivalves. They don't have heads or limbs or external genitalia. ${ }^{20}$ Even flowers have heads and trees have limbs.

Upon arrival, Isle Royale appears to have all the charisma of, well, a mussel. I overheard one visitor remark, "If you like water, rocks and trees, this is your kind of place," and another commented that, "It's pretty much like Maine, but a lot smaller." The island is a fine example of boreal forest, which some wags have renamed "boring forest" given its ecological monotony. And even fewer people would visit were it not a National Park. The island is sort of like the least popular cheerleader who gets more dates than other girls but only because she's on the squad. But this is why I've come to appreciate this remote place and its humble creatures. Neither one is flashy or mesmerizing. If Yellowstone is a National Park foldout, then Isle Royale is my wife in a flannel nightgown. ${ }^{21}$

Isle Royale is like a good life or a long marriage. It has its ups and downs but no grand canyons or towering peaks (the high point is a mere 240 meters above the lake). The island, as with its mussels, manifests a serene continuity. There are storms to be weathered, of course. But most days pass with lots of quiet and little drama. In a society that craves stimulation, the island-mussel offers serenity - untamed tranquility without iconic spectacles like Half Dome, Crater Lake, the Tetons, Long's Peak, or Old Faithful. There are no "must see" things or "must do" happenings on the island. Even missing the mussels will not ruin an otherwise memorable visit.

\footnotetext{
${ }^{18}$ I'm keenly aware of the literature on the philosophy of wilderness - and this is a very complicated subject. In fact, Isle Royale is a wonderful case study in this field. Some would contend that recovered-versus-pristine is a false dichotomy, but others have argued that causal-historical processes are critical to an understanding of wilderness. In sum, 'wilderness' is a social construct - rather than a 'natural kind' — but some constructs are better (more useful, coherent, etc.) than others.

${ }^{19}$ As a reviewer hastened to point out, there is a rather more complicated story than I've summarized in a single sentence. But remember, essays are like models and tactical simplification is essential. If we want a 1:1 model of the world, we can just use the world itself.

${ }^{20}$ Having been chided by a biologist for not doing my job as a nature writer because I failed to expound on the similarities among animals, I can only suggest that alien qualities can be much more intriguing that familiar features. And not every creature needs to be like us - or liked by us - to enchant us.

${ }^{21}$ Another note to the political correctors: Calm down. I'm not a misogynist just because I alluded to high school sociology. Nor am I objectifying women by noting that photos in men's magazines don't look like anyone I've ever seen in real life (but then, I didn't date cheerleaders).
} 
Writing about mussels and Isle Royale is hardly a great literary achievement. But maybe winning Pulitzer prizes and gold medals is overrated. Quite frankly, most people are superlatively average in most ways. My friends and I won't go to the Olympics; we'll spend most of our days burrowed into the sediment of work and family. Our lives are more like the placid mussels of Isle Royale than the athletic muscles of Michael Phelps. The places we love are more like a cabin on Scoville point than a medal stand in the Olympic stadium. The path of our lives resembles the Greenstone Ridge Trail more than the glory of the 100-meter sprint. And at least my moments of enlightenment are more like the glow of a Coleman lantern than the ignition of the Olympic flame.

I am not exceptionally interesting, complicated, fragile, mysterious, beautiful, wealthy, virtuous, or frightening. Nor are the people I love. These last lines are being written by gaslight in the Dassler cabin while my wife knits a sweater after a long day's hike extended by our compulsive thimbleberry picking. Although I enjoy the thrill of geysers, canyons, craters, peaks, and cliff dwellings, sometimes it's good to be in a place where your heartbeat slows rather than races - a place where you can be alive without moving a muscle.

\section{Acknowledgments}

The author served as the artist-in-residence at Isle Royale National Park in the summer of 2012 and would like to gratefully acknowledge the insights, conversations, hospitality, and assistance provided by Greg Blust, Chris and Peg Gale and Allan West of Isle Royale NP.

\section{Literature Cited}

Burkland, J. and R. Root. 2000. The Island Within Us: Isle Royale Artists in Residence 1991-1998. Isle Royale Natural History Association. Houghton, Michigan, USA. 160 pp.

Cochrane, T. 1987. Place, People, and Folklore: An Isle Royale Case Study. Western Folklore 46: 120. http://dx.doi.org/10.2307/1500014

Gosling, E. 2003. Bivalve Molluscs: Biology, Ecology and Culture. Wiley-Blackwell. Malden, Massachusetts, USA. 456 pp. http://dx.doi.org/10.1002/9780470995532

Martin, V. 2012. The Intimate Archipelago. The Greenstone (National Park newspaper). Isle Royale and Keweenaw Parks Association. Houghton, Michigan, USA. pg. 1.

Peterson, R. 2008. "Letting nature run wild in the National Parks," pp. 645-663, In, M. P. Nelson and J.B. Callicott (Editors). The Wilderness Debate Rages On. University of Georgia Press. Athens, Georgia, USA 723 pp.

Strayer, D. L. 2008. Freshwater Mussel Ecology: A Multifactor Approach to Distribution and Abundance. University of California Press. Berkeley, California, USA. 216 pp.

Sturm, C. F., Pearce, T. A. and A. Valdés (Editors). 2006. The Mollusks: A Guide to Their Study, Collection, and Preservation. Universal Publishers. Boca Raton, Florida. 445 pp.

United States National Park Service. "Isle Royale National Park: Nature \& Science: Animals: Mollusks," http://www.nps.gov/isro/naturescience/mollusks.htm, accessed 2 January 2013.

Voshell, J. R. and A.B. Wright. 2002. A Guide to Common Freshwater Invertebrates of North America. McDonald and Woodward. Granville, Ohio, USA. 456 pp. 